\title{
Wylie-Johnson analysis of adolescents of Afro-Brazilian descent with normal occlusion: investigation of the mean values
}

\author{
Análise de Wylie-Johnson em melanodermas com oclusão normal: determinação dos valores médios
}

\author{
Lígia Maria LORENZI \\ Darcy Flávio NOUER² \\ Ivana Uglik GARBUI \\ Vânia FONTANELLA ${ }^{3}$ \\ Nelson PADILHA ${ }^{1}$ \\ Paulo Roberto Aranha NOUER ${ }^{1}$
}

\section{ABSTRACT}

\section{Objective}

The purpose of this study was to evaluate mean cephalometric measurements for a group of individuals of Afro-Brazilian descent using the Wylie-Johnson analysis, and to investigate the presence of sexual dimorphism.

\section{Methods}

Thirty-six lateral radiographs of the head of African-Brazilians were used. Subjects were 10 to 14 years old and had clinically normal occlusion, all permanent teeth, and no history of orthodontic treatment.

\begin{abstract}
Results

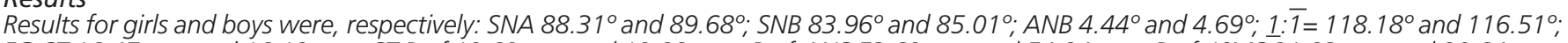
FG-ST $16.47 \mathrm{~mm}$ and $16.12 \mathrm{~mm}$; ST-Pmf $19.69 \mathrm{~mm}$ and $19.88 \mathrm{~mm} ;$ Pmf-ANS $53.69 \mathrm{~mm}$ and $54.84 \mathrm{~mm} ;$ Pmf-1 ${ }^{\circ} \mathrm{MS} 21.83 \mathrm{~mm}$ and $20.64 \mathrm{~mm}$; FG-Pg $108.19 \mathrm{~mm}$ and $108.45 \mathrm{~mm}$; FPL -MPL 27.48 and 27.65'; TAFH $111.06 \mathrm{~mm}$ and $112.26 \mathrm{~mm}$; UAFH $45.26 \mathrm{~mm}$ and $45.38 \mathrm{~mm}$; LAFH $65.80 \mathrm{~mm}$ and $66.88 \mathrm{~mm}$; FG-FPL $1.069 \mathrm{~mm}$ and $-2.086 \mathrm{~mm} ; \mathrm{MBL} 70.24 \mathrm{~mm}$ and $69.67 \mathrm{~mm}$; MRH $51.89 \mathrm{~mm}$ and $53.70 \mathrm{~mm} ; \mathrm{gonial}$ angle $129.27^{\circ}$ and $129.28^{\circ}$. Results of Student's-t test (=5\%) did not show any sexual dimorphism. Results of descriptive statistics were similar for the individuals of Afro-Brazilian descent in the study.
\end{abstract}

\section{Conclusion}

Individuals of African descent had bimaxillary protrusion, a more acute interincisal angle, a larger inferior facial height, and a markedly convex profile.

Indexing terms: African Continental Ancestry Group. Cephalometry. Orthodontics.

\section{RESUMO}

\section{Objetivo}

Avaliar as medidas cefalométricas médias para um grupo de indivíduos melanodermas usando a análise de Wylie \& Johnson e também investigar a presença de dimorfismo sexual.

\section{Métodos}

Foram usadas 36 telerradiografias em norma lateral de indivíduos melanodermas, entre 10 e 14 anos de idade, com oclusão clinicamente normal, todos os dentes permanentes e sem histórico de tratamento ortodôntico.

\section{Resultados}

Os resultados para os sexos feminino e masculino foram respectivamente: $\mathrm{SNA}=88,31^{\circ} \mathrm{e} 89,68^{\circ} ; \mathrm{SNB}=83,96^{\circ}$ e $85,01^{\circ} ; \mathrm{ANB}=4,44^{\circ} \mathrm{e}$ $4,69^{\circ} ; 1: \bar{T}=118,18^{\circ}$ e $116,51^{\circ} ; \mathrm{FG}-\mathrm{ST}=16,47 \mathrm{~mm}$ e $16,12 \mathrm{~mm} ;$ ST-Fpm $=19,69 \mathrm{~mm}$ e $19,88 \mathrm{~mm} ; \mathrm{Fpm}-\mathrm{Spna}=53,69 \mathrm{~mm}$ e $54,84 \mathrm{~mm} ; \mathrm{Fpm}-6$ $=21,83 \mathrm{~mm}$ e 20,64mm; FG-Pg = 108,19mm e 108,45mm; PIF.PIM = 27,48 e 27,65; AFAT =111,06mm e 112,26mm; AFAS = 45,26mm e 45,38mm; AFAl = 65,80mm e 66,88mm; FG-PIF =-1,069mm e-2,086mm; Go-Me = 70,24mm e 69,67mm; Con-Go = 51,89mm e 53,70mm; Gon $=129,27$ e 129,38. A análise estatística descritiva dos dados mostrou homogeneidade entre os mesmos. Não foi observado dimorfismo sexual (teste t de Student, $\alpha=5 \%$ ).

\section{Conclusão}

Os dados sugerem que os indivíduos melanodermas estudados apresentam biprotrusão maxilar, ângulo interincisal mais agudo, altura facial inferior maior e perfil convexo acentuado.

Termos de indexação: Grupo com ancestrais do continente africano. Circunferência craniana. Ortodontia.

\footnotetext{
${ }^{1}$ Faculdade São Leopoldo Mandic, Curso de Odontologia, Departamento de Ortodontia. Rua José Rocha Junqueira, 13, Swift, 13061-140, Campinas, SP, Brasil. Correspondência para / Correspondence to: PRA NOUER.E-mail: <nouerp3@gmail.com >.

${ }^{2}$ Universidade Estadual de Campinas, Faculdade de Odontologia, Departamento de Odontologia Infantil. Piracicaba, SP, Brasil.

${ }^{3}$ Universidade Luterana do Brasil, Curso de Odontologia. Canoas, RS, Brasil
} 


\section{INTRODUCTION}

The concern about taking measurements of the head for anthropological purposes dates back to the mid-eighteenth century. The orthodontic diagnosis and treatment plan were prepared using only plaster casts and craniometric methods. Due to the low precision of these methods in analysis of the patient, many researchers sought means that would allow measurements in patients with the same facility as they were performed in dry skulls.

Broadbent ${ }^{1}$ recommended a method that made it possible to obtain successive, standardized radiographs of the head; that is, teleradiographs, enabling the professional to detect the alterations caused by growth and/or orthodontic treatment. In the same year, Hofrath also presented a technique for obtaining standardized radiographs. Interpretation of the tracings in a teleradiograph by cephalometry, a technique that enables craniofacial evaluation by means of radiographs taken within a constant pattern, opened up new horizons for Orthodontics.

Brodie $^{2}$ presented a study based on the collection of Broadbent cephalometric radiographs to study the craniofacial growth of children from the age of three months to eight years of age with Downs ${ }^{3}$, and presented one of the first cephalometric analyses effectively used in the diagnosis and planning of orthodontic cases.

According to Krogman ${ }^{4}$ with the passing years, cephalometric analyses appeared, which were for the purpose of defining parameters of normality for a certain population group. These analyses provide angular and linear measurements of Caucasian individuals, with normal occlusion and satisfactory facial esthetics, and are useful guides in the preparation of orthodontic diagnosis and treatment plan. However, the values found for the different populations are not the same, as there are racial, ethnic and age-related factors that make them valid exclusively for the studied group in particular.

The contribution of persons of Afro-Brazilian descent to our culture is something unquestionable, such as in music, language, religion, culinary arts, customs and education of the Brazilian people. At present we have verified diverse contemporary studies in sociology, history, geography, philosophy and psychology, among other fields of knowledge, with great interest in problems relative to the Afro-descendants.

It has therefore become necessary to develop studies with a view to establishing normal morphogenetic patterns for the dento-skeletal structures among the different ethnic groups. As from the 1950s, many studies appeared, seeking to determine the cephalometric patterns that would be representative of the different ethnicities.

Cephalometric analysis, or the Wylie ${ }^{5}$ cephalogram evaluates the balance between the segments of the face, analyzing the proportions, and eliminating the error of simply evaluating isolated variables. Two different analyses were idealized: The first in the antero-posterior and the second in the vertical direction, constituted of measurements and proportions of the segments between the Frankfurt and Mandibular planes ${ }^{6}$.

Thus, the aim of this study was to perform cephalometric measurements in individuals of AfroBrazilian descent by the Wylie \& Johnson analysis, and some of the variables of the Steiner ${ }^{7}$ analysis (SNA, SNB, $A N B$ and the interincisal angle), and verify the presence of sexual dimorphism.

\section{METHODS}

As the sample for the study, radiographs in lateral norm were used, obtained from the record charts of the Scientific Documentation Center of the PostGraduate Course in Dentistry, Piracicaba Dental School, State University of Campinas. The criteria for inclusion in the study were: Stage of mixed or permanent dentition, descendants of Afro-Brazilian parents and grandparents, of both genders, aged between 10 and 14 years, molars in Angle's Class I, canines in normal key of occlusion, and coincident midline. The following exclusion criteria were considered: History of orthodontic and/or orthopedic treatment, absence of teeth, crowding or giroversions, deleterious oral habits, and facial or dental asymmetry.

The cephalometric analysis proposed by Wylie \& Johnson ${ }^{6}$ was applied in the selected teleradiographs for evaluation of antero-posterior dysplasia (Figure 1), vertical dysplasia (Figure 2) and some of the variables from the analysis of Steiner ${ }^{7}$, (Figure 3). The tracings were based on the Nouer ${ }^{8}$ Manual of Cephalometry applied in radiology and orthodontics, and were performed twice by one and the same operator, with an interval of 10 days between tracings. The results obtained were submitted to descriptive analysis for determination of the means, standard-deviations and maximum and minimum values; and to the Student's-t test at a level of significance of $0.05 \%$, to compare the differences between genders.

This study was approved by the Research Ethics Committee of the São Leopoldo Mandic Dental School, Protocol No.821, in accordance with the Ministry of Health Resolution 196/1996. 


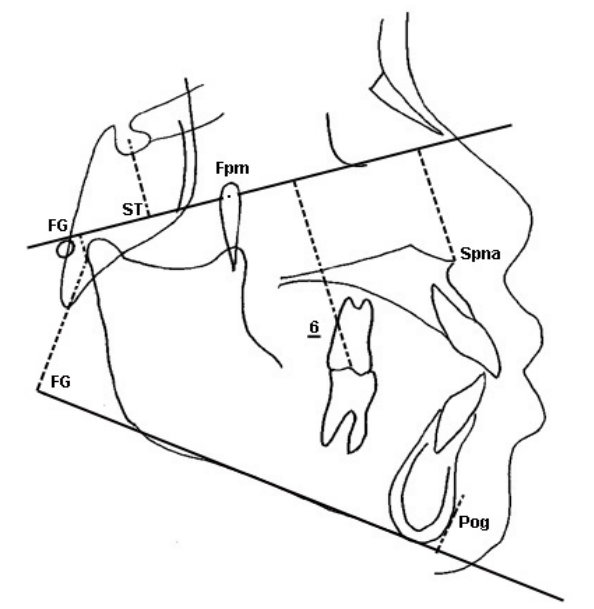

Figure 1. Measurements used for analysis of antero-posterior dysplasia.

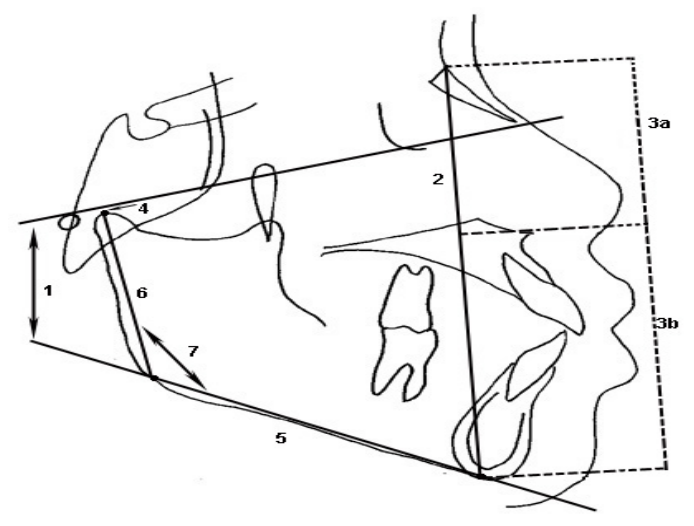

Figure 2. Vertical Dysplasia. 1: PoOr-PM; 2: N-Me; 3a: N-ENA; 3b: ENA-Me; 4: Glenoid Fossa - Frankfurt Plane; 5: Go-Me; 6: Cd-Go; 7: Cd-GoMe.

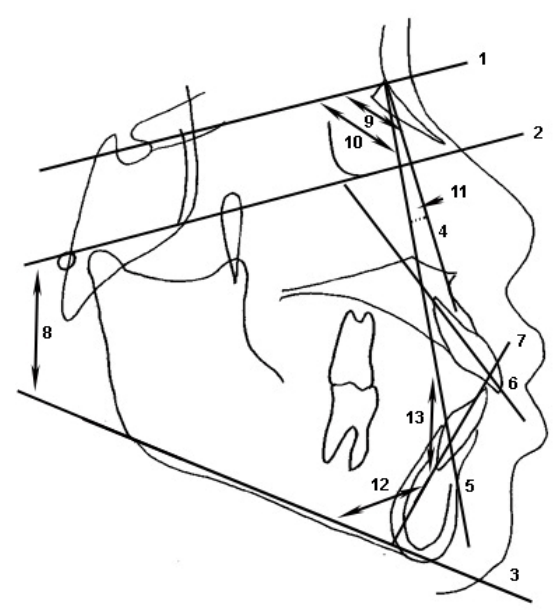

Figure 3. Lines, Cephalometric Planes and Angular Measurements Lines: 1) SN (selanasion); 2) Po-Or (porion-orbital); 3) GoMe (gonion-mentonian); 4) NA (nasion-point A); 5) NB (nasion-point B); 6) Permanent maxillary central incisor long axis; 7) Permanent mandibular central incisor long axis. Planes: 8) FMA (Po-Or Go-Me). Angles: 9) SNA; 10) SNB; 11) ANB; 12) IMPA; 13) $1: 1$.

Source: Nouer

\section{RESULTS}

Based on the inclusion and exclusion criteria, 36 teleradiographs were selected, of which 20 were of individuals of the female gender and 16 of the male gender. The operator error, according to the repeatability and reproducibility analysis (Gage R\&R), ranged between $1.96 \%$ and $7.25 \%$, below the ideal tolerance limit of $10 \%$. The Student's-t test for two samples was used to verify the presence of sexual dimorphism and revealed that the means of the two genders did not differ statistically between them (Table 1).

Table 1. Means \pm standard deviation and test for verifying presence of sexual dimorphism.

\begin{tabular}{|c|c|c|c|c|}
\hline Variable & Caucasian & $\begin{array}{l}\text { Afro-Brazilian } \\
\text { descendant } \\
\text { Female gender }\end{array}$ & $\begin{array}{l}\text { Afro-Brazilian-descendant } \\
\text { Male gender }\end{array}$ & $\mathrm{p}^{*}$ \\
\hline SNA $\left(^{\circ}\right)$ & $82.00 \pm 2.00$ & $88.31 \pm 4.38$ & $89.68 \pm 4.79(81.25$ a 97.50$)$ & 0.378 \\
\hline $\operatorname{SNB}\left({ }^{\circ}\right)$ & $80.00 \pm 2.00$ & $83.96 \pm 3.77$ & $85.01 \pm 3.96$ & 0.424 \\
\hline ANB $\left(^{\circ}\right)$ & $2.00 \pm 2.00$ & $4.44 \pm 2.31$ & $4.69 \pm 2.62$ & 0.763 \\
\hline 1: $1\left(^{\circ}\right)$ & 130.00 & $118.8 \pm 8.84$ & $116.51 \pm 6.84$ & 0.538 \\
\hline $\mathrm{FG}-\mathrm{ST}(\mathrm{mm})$ & 17.00 & $16.47 \pm 3.55$ & $16.12 \pm 3.00$ & 0.754 \\
\hline ST-Fpm (mm) & 17.00 & $19.69 \pm 1.95$ & $19.88 \pm 2.30$ & 0.785 \\
\hline Fpm-Spna (mm) & 52.00 & $53.69 \pm 2.62$ & $54.84 \pm 3.38$ & 0.251 \\
\hline $\mathrm{Fpm}-\underline{6}(\mathrm{~mm})$ & 16.00 & $21.83 \pm 3.00$ & $20.64 \pm 4.11$ & 0.325 \\
\hline FG-Pg (mm) & 101.00 & $108.19 \pm 6.02$ & $108.45 \pm 3.90$ & 0.883 \\
\hline PIF.PIM (mm) & 25.00 & $27.48 \pm 5.09$ & $27.65 \pm 5.75$ & 0.927 \\
\hline AFAT $(\mathrm{mm})$ & $113.02 \pm 0.67$ & $111.06 \pm 5.56$ & $112.26 \pm 7.37$ & 0.581 \\
\hline AFAS (mm) & $50.65 \pm 0.38$ & $45.26 \pm 3.74$ & $45.38 \pm 3.30$ & 0.916 \\
\hline AFAl $(\mathrm{mm})$ & 62.37 & $65.80 \pm 3.77$ & $66.88 \pm 5.34$ & 0.484 \\
\hline FG-PIF (mm) & $0.54 \pm 0.38$ & $-1.069 \pm 1.485$ & $-2.086 \pm 1.905$ & 0.080 \\
\hline Go-Me (mm) & $67.30 \pm 0.46$ & $70.24 \pm 4.50$ & $69.67 \pm 3.68$ & 0.687 \\
\hline Con-Go (mm) & $54.81 \pm 0.56$ & $51.89 \pm 4.61$ & $53.70 \pm 3.26$ & 0.687 \\
\hline Con.GoMe $\left(^{\circ}\right)$ & $122.49 \pm 0.71$ & $129.27 \pm 4.08$ & $129.38 \pm 4.49$ & 0.941 \\
\hline
\end{tabular}

$p$-values lower than 0.5 indicate statistically significant difference.

\section{DISCUSSION}

The different cephalometric analyses used at present were established up to the middle of the Twentieth Century and the values of normality recommended were obtained from a casuistic of Caucasians. However, there was evident need to know the alterations in the linear and angular measurements of the dento-skeletal structures during growth, in addition to establishing their values in the different ethnic groups ${ }^{9-15}$.

In Individuals of Afro-Brazilian descent there are few studies that have been concerned with the 
cephalometric evaluation of this ethnic group in Brazil, with the outstanding studies being those of Silva ${ }^{9}$, Moraes et al. ${ }^{11}$, Araújo \& Sakima ${ }^{12}$, Fortes ${ }^{15}$, Henriques \& Freitas ${ }^{16}$, Silva \& Oliveira ${ }^{17}$, Nouer et al. ${ }^{18}$, Magnani et al. ${ }^{19}$, de Freitas et al. ${ }^{20}$, Janson et al. ${ }^{21}$, Sobreira et al. ${ }^{22}$ and Carvalho et al. ${ }^{23}$.

When using certain cephalometric points in evaluating the balance of the facial segments, Wylie \& Johnson $^{6}$ eliminated the errors of evaluating isolated variables. However, there were no studies about their application in Individuals of Afro-Brazilian descent, which motivated the present study.

Initially, the statistical test for evaluating sexual dimorphism revealed that there were no differences between the genders.

The value found in the relationship of the maxilla with the base of the skull (SNA) showed similarity to the results found by Silva ${ }^{9}$, Fonseca \& Klein ${ }^{10}$, Moraes et al. ${ }^{11}$, Araújo \& Sakima ${ }^{12}$ and Bailey \& Taylor ${ }^{14}$. D'Aloísio \& Pangrasio-Kulbersh ${ }^{13}$ found higher values in the male gender than those found in the present study, whereas Janson et al. ${ }^{21}$ found lower values for both genders, since in his study no statistically significant difference was found for the male and female genders.

For the relationship of the mandible with the base of the skull (SNB), the results found in both genders were similar to those found by Silva ${ }^{9}$, Fonseca \& Klein $^{10}$, Moraes et al. ${ }^{11}$ and Araújo \& Sakima ${ }^{12}$. In the study of D'Aloísio \& Pangrazio-Kulbersh ${ }^{13}$ only the values for the female gender were shown to be similar to those of the present study, while the values for the male gender differed only from those in the study of D'Aloísio \& Pangrasio-Kulbersh ${ }^{13}$.

In the maxillo-mandibular relationship (ANB) there was similarity of the results with those of Silva ${ }^{9}$, Fonseca \& Klein ${ }^{10}$, Moraes et al. ${ }^{11}$, Araújo \& Sakima ${ }^{12}$, D'Aloísio \& Pangrazio-Kulbersh ${ }^{13}$ and Bailey $\&$ Taylor $^{14}$. In the studies of Fonseca \& Klein ${ }^{10}$ and Moraes et al. ${ }^{11}$, there was agreement of values only in the female gender.

The interincisal angle values $(1: \overline{1})$ were close to those of Bailey \& Taylor14 in both genders, and showed similarity to those of Fonseca \& Klein ${ }^{10}$ only in the female gender.

The variable that relates the glenoid cavity to the base of the skull (FG-ST) presented a lower value than that suggested by Wylie \& Johnson ${ }^{6}$, as it was an indication of mandibular prognathism, characteristic of this ethnic group. The antero-posterior measurement of this casuistic of Individuals of Afro-Brazilian descent; that is, the relationship of the maxilla with the base of the skull (STFpm), position of the first molar with the maxilla (Fpm-6), size of the mandible (FG-ST) and maxilla (Fpm-Spna) were shown to be larger than the standard values proposed by Wylie \& Johnson ${ }^{6}$, indicating a more protruded maxilla and mandible in relation to the base of the skull. Silva ${ }^{9}$ found a value for length of the mandible similar to that presented in the present study, however, his finding for the size of the maxilla was slightly smaller.

In the vertical dimensions, vertical dysplasia of which the main indicator is the inclination of the mandibular plane (FG-Pg), the total (AFAT), superior (AFAS) and inferior (AFAl) facial heights were observed. The total facial height value (AFAT) was similar to that found by Silva ${ }^{9}$ and smaller than that suggested by Wylie \& Johnson ${ }^{6}$. Moreover, the superior facial height (AFAS) was smaller, and the inferior (AFAl) was larger than that proposed by Wylie \& Johnson ${ }^{6}$. In the angle of the Frankfurt plane with the mandibular plane (PIF.PIM), the value found was higher than the standard value of Wylie \& Johnson ${ }^{6}$, showing vertical dysplasia.

In the relationship of the glenoid cavity with the Frankfurt plane (FG-PIF) the distance found was longer than that proposed by Wylie \& Johnson ${ }^{6}$, suggesting a more antero-inferior mandibular position. The mandibular ramus height (Con-Go) in this sample presented a lower value, and the length of the mandibular body and gonion angle (Con-GoMe) showed higher values than those of Wylie \& Johnson ${ }^{6}$.

\section{CONCLUSION}

The values for Individuals of Afro-Brazilian descent were higher when compared with those established, taking the values for Caucasians as reference. No sexual dimorphism was found in the individuals of Afro-Brazilian descent in the present sample, analyzed by the WylieJohnson cephalogram.

From the foregoing, it was concluded that the standards and patterns of one ethnic group cannot be used without modifications for another group, especially Individuals of Afro-Brazilian descent who must have their own measurements.

\section{Collaborators}

L LORENZI participated in the elaboration and development of the research, and writing the article. PRA NOUER participated in guiding the research and in writing the article. IU GARBUI, DF NOUER, V FONTANELLA and N PADILHA participated in writing the article. 


\section{REFERENCES}

1. Broadbent $\mathrm{BH}$. A new X-ray technique and its application to orthodontia. Angle Orthod. 1931;1(2):45-66.

2. Brodie AG. On the growth pattern of the human head from the third month of eight years. Am J Anat. 1941;68(2):209-62. doi: 10.1002/aja.1000680204.

3. Downs WB. Variation in facial relationships: their significance in treatment and prognosis. Angle Orthod. 1949;19(3):145-55. doi: 10.1016/0002-9416(48)90015-3.

4. Krogman WM. The meaningful interpretation of growth and growth data by the clinician. Am J Orthod. 1958;44(6):411-32. doi: 10.1016/0002-9416(58)90002-2.

5. Wylie WL. The assessment of anteroposterior dysplasia. Angle Orthod. 1947;17(3):97-109.

6. Wylie WL, Johnson EL. Rapid evaluation of facial dysplasia in the vertical plane. Angle Orthod. 1952;22(3):165-82.

7. Steiner C. Cephalometrics for you and me. Am J Orthodont. 1953;39(10):729-55. doi: 10.1016/0002-9416(53)90082-7.

8. Nouer PRA. Cefalometria aplicada em radiologia e ortodontia. Campinas: São Leopoldo Mandic; 2003.

9. Silva AN. O esqueleto craniofacial de crianças melanodermas: estudo radiocefalométrico [dissertação]. Piracicaba: Universidade Estadual de Campinas; 1975.

10. Fonseca RJ, Klein WD. A cephalometric evaluation of American Negro women. Am J Orthod. 1978;73(2):152-60. doi: 10.1016/0002-9416(78)90185-9.

11. Moraes C, Freitas MR, Henriques JFC. Cefalometria: determinação do padrão esquelético dos adolescentes melanodermas brasileiras com "oclusão normal". Ortodontia. 1988;21(2):4-14.

12 Araújo MBB, Sakima T. Comparação cefalométrica entre negróides e caucasóides. RGO - Rev Gaúcha Odontol. 1989;37(3):225-8.

13. D'Aloisio D, Pangrazio-Kulbersh V. A comparative and correlational study of the cranial base in North American blacks. Am J Orthod Dentofacial Orthop. 1992;102(5):449-55. doi: 10.1016/S0889-5406(05)81192-8.

14. Bailey KL, Taylor RW. Mesh diagram cephalometric norms for Americans of African descent. Am J Orthod Dentofacial Orthop. 1998;114(2):218-23. doi: 10.1053/od.1998.v114.a87104.
15. Fortes LAP. Avaliação de medidas cefalométricas de indivíduos negros, brasileiros, portadores de oclusão excelente [dissertação]. Rio de Janeiro: Universidade Federal do Rio de Janeiro; 2000.

16. Henriques JFC, Freitas MR. Determinação da medida Wits em jovens brasileiros melanodermas com "oclusão normal" e comparação com a dos jovens leucodermas. Ortodontia. 1990;23(2):4-10.

17. Silva JJ, Oliveira MG. Estudo cefalométrico computadorizado, em forma frontal, de dimensões lineares e angulares em indivíduos da raça negra. Rev Fac Odontol Porto Alegre. 1997;38(1):7-11.

18. Nouer DF, Magnani MBBA, Vedovello Filho M, Kuramae M, Corrêa FA, Inoue RC. Determinação do valor médio do índice de altura facial em melanodermas com oclusão normal. Ortodontia. 2003;36(2):71-6.

19. Magnani MBBA, Nouer DF, Nouer PRA, Pereira Neto JS, Garbui $I U$, Böeck EM. Assessment of the nasolabial angle in young Brazilian black subjects with normal occlusion. Braz Oral Res. 2004;18(3):233-7. doi: 10.1590/\$1806-83242004000300010.

20. De Freitas LM, Pinzan A, Janson G, Freitas KM, de Freitas MR, Henriques JF. Facial height comparison in young white and black Brazilian subjects with normal occlusion. Am J Orthod Dentofacial Orthop. 2007;131(6):706. e 1-6.

21. Janson G, Quaglio CL, Pinzan A, Franco EJ, de Freitas MR. Craniofacial characteristics of Caucasian and Afro-Caucasian Brazilian subjects with normal occlusion. J Appl Oral Sci. 2011; 19(2):188-24.

22. Sobreira CR, Vilani GNL, Siqueira VCV. Comparative study of facial proportions between Afro-Brazilian and white Brazilian children from 8 to 10 years of age. Dental Press J Orthod. 2011;16(2):85-93.

23. Carvalho EN, Nouer DF, Garbui IU, Nouer PRA. Relationship of the hyoid bone and posterior surface of the tongue for class Il division 1 orthodontic patients. RGO - Rev Gaúcha Odontol. 2013;61(1):61-8.
Received on: 24/11/2012

Final version resubmitted on: 17/5/2013

Approved on:13/9/2013 
